Article

\title{
Long-Term Subsidence Monitoring of the Alluvial Plain of the Scheldt River in Antwerp (Belgium) Using Radar Interferometry
}

\author{
Pierre-Yves Declercq ${ }^{1, *}$, Pierre Gérard ${ }^{2}\left(\mathbb{D}\right.$, Eric Pirard ${ }^{3}$, Jan Walstra ${ }^{1}\left[\right.$ and Xavier Devleeschouwer ${ }^{1}(\mathbb{D}$ \\ 1 Royal Belgian Institute of Natural Sciences, O.D. Earth and History of Life, Geological Survey of Belgium, \\ Rue Jenner 13, 1000 Brussels, Belgium; jwalstra@naturalsciences.be (J.W.); \\ xdevleeschouwer@naturalsciences.be (X.D.) \\ 2 BATir Department, Université Libre de Bruxelles (ULB), CP194/02, Avenue F.D. Roosevelt 50, 1050 Bruxelles, \\ Belgium; piergera@ulb.ac.be \\ 3 Department ARGENCO/Gemme-GEO3, Université de Liège (ULg), Allée de la découverte, 9-Bat. B 52/, \\ 4000 Liège, Belgium; eric.pirard@ulg.ac.be \\ * Correspondence: pydeclercq@naturalsciences.be; Tel.: +32-2-788-76-56
}

check for updates

Citation: Declercq, P.-Y.; Gérard, P.; Pirard, E.; Walstra, J.; Devleeschouwer, $X$. Long-Term Subsidence Monitoring of the Alluvial Plain of the Scheldt River in Antwerp (Belgium) Using Radar Interferometry. Remote Sens. 2021, 13, 1160. https://doi.org/10.3390/rs 13061160

Academic Editor: Nicola Casagli

Received: 10 February 2021

Accepted: 16 March 2021

Published: 18 March 2021

Publisher's Note: MDPI stays neutral with regard to jurisdictional claims in published maps and institutional affiliations.

Copyright: (c) 2021 by the authors. Licensee MDPI, Basel, Switzerland. This article is an open access article distributed under the terms and conditions of the Creative Commons Attribution (CC BY) license (https:// creativecommons.org/licenses/by/ $4.0 /)$.

\begin{abstract}
The coupled effects of climate change, sea-level rise, and land sinking in estuaries/alluvial plains prone to inundation and flooding mean that reliable estimation of land movements/subsidence is becoming more crucial. During the last few decades, land subsidence has been monitored by precise and continuous geodetic measurements either from space or using terrestrial techniques. Among them, the Persistent Scaterrer Interferometry (PSInSAR) technique is used on the entire Belgian territory to detect, map and interpret the identified ground movements observed since 1992. Here the research focuses on one of the biggest cities in Belgium that became the second European harbour with giant docks and the deepening of the Scheldt river allowing the navigation of the largest container vessels. The areas along the embankments of the Scheldt river and the harbour facilities are associated to Holocene fluviatile deposits overlain by recent landfills. These sedimentary deposits and human-made landfills are affected by important and ongoing land subsidence phenomena. The land subsidence process is highlighted by an annual average Line of Sight (LOS) velocity of about -3.4 mm/year during the years 1992-2001 (ERS1/2 datasets), followed by an annual average LOS velocity of about $-2.71 \mathrm{~mm} /$ year and $-2.11 \mathrm{~mm}$ /year, respectively, during the years 2003-2010 (ENVISAT) and 2016-2019 (Sentinel 1A). The Synthetic Aperture Radar (SAR) imagery data indicate a progressive decrease in the average annual velocities on a global scale independently of important local variations in different districts along the Scheldt river. On the contrary, the city centre and the old historic centre of Antwerp are not affected by negative LOS velocities, indicating stable ground conditions. A geological interpretation of this difference in settlement behaviour between the different areas is provided.
\end{abstract}

Keywords: PSInSAR; InSAR; subsidence; estuary; antwerp

\section{Introduction}

The subsidence rate along the coastal lowland areas and the global sea level rise can seriously damage important anthropic infrastructures such as bridges, roads, railways, buildings and harbours. In China, several cities have been affected by severe land subsidence for which the economic loss was estimated to reach 100 million \$/year [1]. The result is that the populations of these areas are under a growing risk of coastal flooding, wetland loss, shoreline retreat and loss of infrastructures. The vulnerability is a result of natural sediment compaction from the removal of oil, gas and water from the delta's underlying sediments, the trapping of sediment in reservoir upstream and floodplain engineering in combination with rising global sea level [2]. The global mean sea level 
rise is estimated to reach $3.05-3.3 \mathrm{~mm} /$ year for the 20th and 21st centuries and will affect 150-630 M inhabitants living along the coastlines depending on low to high carbon emissions [3]. The origin of the subsidence in delta areas remain controversial but, in most cases, it is generally associated with the natural compaction of Holocene unconsolidated and loose deposits. In the case of the Mississippi delta [4], the rates are ranging between $-5 \mathrm{~mm} /$ year at millennial-scale to $-10 \mathrm{~mm}$ /year at the timescale of decades to centuries. These compaction rates have been estimated on radiocarbon dated sediment cores and are explained partly by the presence of peat layers in the sedimentary succession. It has been found that the compaction of peat layers is quite rapid in the uppermost (10-15 m) of the sequence, but the compaction of deeper Holocene strata is also significant. Compaction rates variabilities in deltas can also be linked to lateral lithological variability associated to the presence of sand bodies, for example, that will drastically reduce the compaction rates of the Holocene strata. These observations suggest that the use of modern geodetic measurements illustrating different subsidence rates in deltas are not necessarily related to any tectonic mechanism [4]. For instance, the Fraser River delta (British Columbia, Canada) has a subsidence rate between -1 and $-2 \mathrm{~mm} /$ year (in this paper, negative velocity will refer to subsidence and positive to uplift) for the Holocene lowlands as deduced from SAR Interferometry (InSAR), levelling and GPS stations vs. $-0.1 \mathrm{~mm} /$ year for the Pleistocene highlands and bedrock areas [5]. Radar interferometry is one of the recent tools for monitoring the intensity, extension and impacts of the settlement in rivers delta, estuaries and coastal zones around the world [5-12]. Land subsidence rates from -1 to $-15 \mathrm{~mm} /$ year were obtained for the Po Delta (Italy) based on a study combining radar interferometry, satellite imagery, seismic survey and geochronological data from core samples [6]. These subsidence rates were linked to compressible Holocene deposits composing the shallowest part of the sedimentary sequence (i.e., the first 30-40 m). ENVISAT SAR imagery was used to identify land subsidence rates in the Pearl River Delta (China) and an average subsidence rate ranging between -2.5 and $-6 \mathrm{~mm}$ /year along the coast is associated to natural compaction of Holocene deposits [7]. On the contrary, high subsidence rates ranging between -4 and $-10.3 \mathrm{~mm} /$ year measured from ENVISAT SAR imagery in the main cities located in the Nile Delta are interpreted as resulting from human activities (i.e., groundwater extraction) [8]. Long-term ground motion analyses using historical C-band satellites are not frequently available in deltaic areas. A recent study of the Po River Delta over the last 25 years (1992-2017) showed increasing subsidence moving from the inland to the coastline with maximum velocities of about $-30 \mathrm{~mm} /$ year in many embankments [9].

In this study, we will estimate the land subsidence along the alluvial plain of the Scheldt river essentially along the Sea Scheldt portion associated to the urbanized metropolitan area of Antwerp. The Scheldt estuary like many estuarine/deltas around the world is sinking due to human activities and becoming vulnerable to flooding. Historical and recent C-band SAR satellites data between 1992 and 2019 are used to assess and estimate the importance of the ground movements. The SAR observations will be focused on two different geological areas located, respectively, along the estuary embankments in the harbour area of Antwerp and underneath the city centre of Antwerp. These two areas are composed by soft and young Quaternary sediments that are prone to settle. However, we will demonstrate that there are clear contrasted settlement behaviours between these two studied areas, and that those differences can be explained by different geological contexts.

\section{Geographical and Geological Settings of the Studied Area}

\subsection{Geographical Context}

The region of interest (ROI) is in the northern part of Belgium along the Scheldt valley till its mouth in the North Sea and comprises the Dutch border, the city centre of Antwerp and the harbour. The river Scheldt originates at Saint Quentin (France) and is rain-fed by a catchment of approximately $21.863 \mathrm{~km}^{2}$, which is drained by the river and its branches to the North Sea near Vlissingen (The Netherlands) [13]. The river Scheldt is situated in the north-western part of France, the western part of Belgium, and the southwestern part 
of The Netherlands. The $355 \mathrm{~km}$ long river can be divided from its source to the mouth into the Upper Sea Scheldt and the tidally influenced part, composed of the Lower Sea Scheldt and the Western Scheldt. In the ROI, two main rivers join the Scheldt: the Durme, and the Rupel (Figure 1). Most of the river basin area in the ROI is urbanized, with an average density of about 477 inhabitants per $\mathrm{km}^{2}$ [13]. The importance of the Scheldt for shipping purposes increased in the 19th century, which led to digging of docks in the polder landscape of the estuary. Since the middle of the 20th century, major industrial and urban development took place. About $16 \%$ of the total surface of the whole estuary was lost in the last century [13]; especially, the surface of the Western Scheldt decreased from 45,000 ha in 1800 to 30,000 ha today and the length of the river became $10.5 \mathrm{~km}$ shorter.

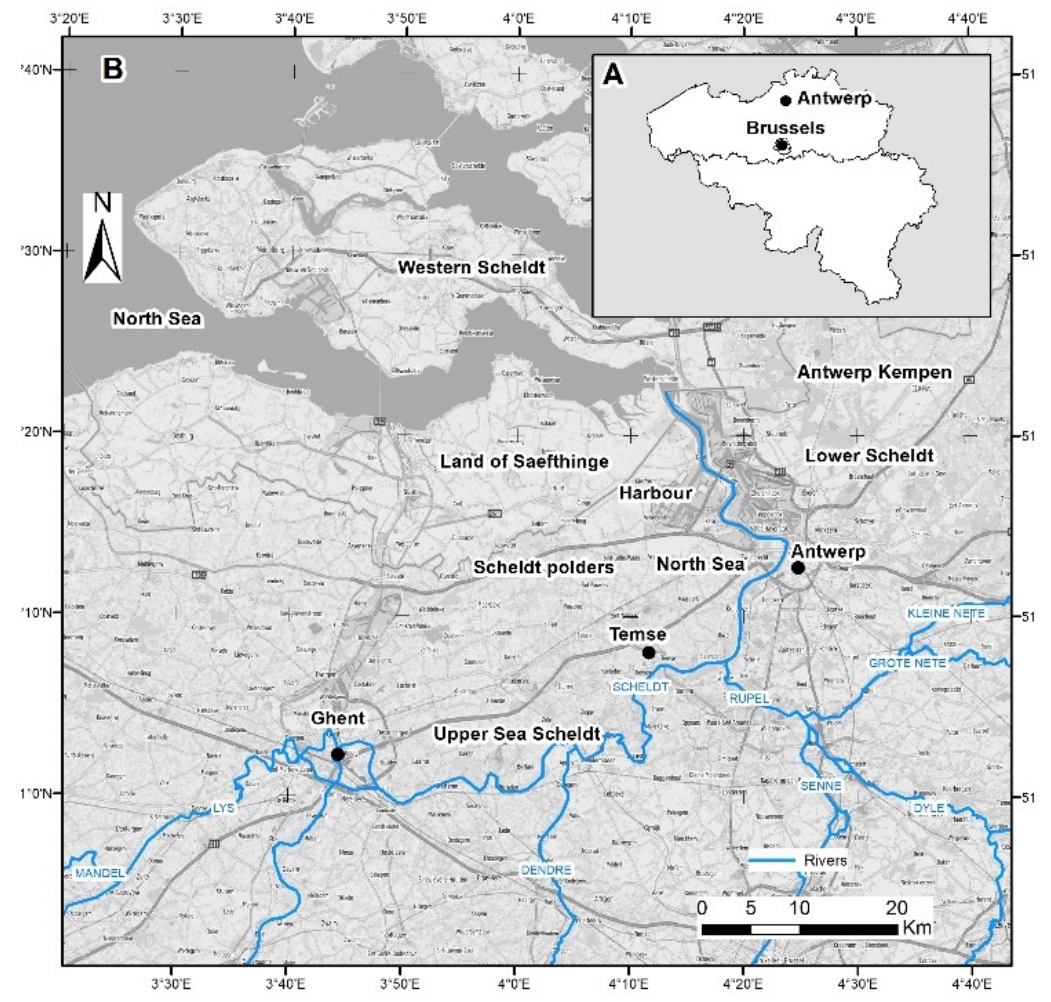

Figure 1. A. Location of Antwerp in Belgium, B. Overview of the Scheldt Estuary.

The Western Scheldt has a complex morphology with flood and ebb channels associated to large mud and sand flats [14], but the upper estuary forms a more narrow, single tidal ebb/flood channel. As a result of tidal asymmetry, sediments accumulate in the upstream part of the Western Scheldt, as more sediment is transported upstream at high tide than is exported at low tide.

Human activities are concentrated in the Lower Sea Scheldt where agglomerations and industries historically developed close to the estuary. The port of Antwerp plays a significant role associated to the intensive urbanized development of Antwerp and the 1.2 million inhabitants in the metropolitan area. The harbour area is highly modified by human activities since the Middle Ages. Polders were created but most of them have disappeared in the last 80 years. The constant natural evolution of the area due to the estuarine conditions implies that the situation remains in a fragile equilibrium. This area is an almost flat low-lying region. The altitude in the Scheldt polders area varies between roughly 0.5 to $5 \mathrm{~m}$, which makes it easily flooded by high tides without the presence of the dikes. The low altitude of the land in comparison with its direct borders is principally due to the drainage of the peat and its extraction since the Roman time until the 15th century along the left bank of the Western Scheldt estuary [15]. In the harbour area, the natural topography was raised by adding a thickness of $8-10 \mathrm{~m}$ of landfills. To the north east at the transition between the Scheldt polders and the Antwerp Kempen area, the topography 
rises from 5 to $30 \mathrm{~m}$ in Kalmthout on the Brabant Wall (Figure 2). The Wase Cuesta is located south of the Polders area and west of the Scheldt on top of the stiff north-dipping clay deposits of the Boom Formation. The cuesta has a steeply sloping front in the south and is bordered by the Scheldt and the Durme rivers. The cuesta is slightly dipping to the north. The maximum height of the Wase Cuesta is approximately $30 \mathrm{~m}$. To the east of the Scheldt. A similar cuesta called the Boom Cuesta is bordered to the south by the Rupel and Nethe rivers. Along the southern and western edges of the cuesta, the topography is strongly affected by the intensive exploitation of the clayey deposits of the Boom Formation for the brick industry [16].

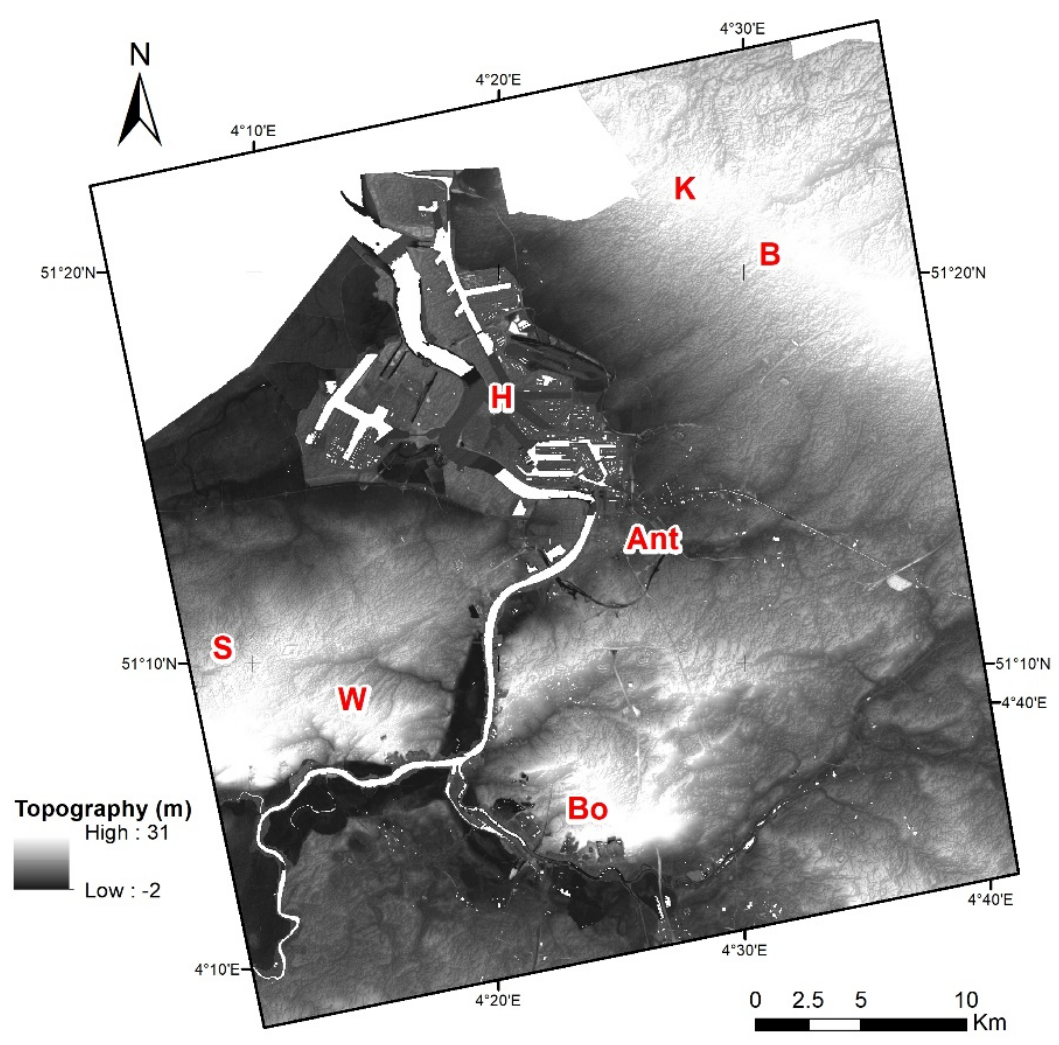

Figure 2. Topography of the studied area in meters. DEM of the Flemish Region 2001. Ant: Antwerp city centre, H: Harbour of Antwerp, S: Sint-Niklaas, Bo: Boom cuesta, K: Kalmthout, B: Brabant Wall, W: Wase cuesta.

\subsection{Geological Context}

\subsubsection{The Late Pleistocene Evolution of the Scheldt}

At the end of the last glaciation the Weichselian at ca 30,000 years BP, the drainage direction of the Scheldt changed completely due to an obstruction of its valley in the northwest. The Scheldt downstream of Ghent shifted its course from the northwest to the east and cut near Hoboken through the Wase-Boomse cuestas. A northern course originated/developed. This direction is kept until the present day. During that period the Scheldt was a sandy braided river. At ca 13,000 BP (late glacial period) the river style changed from a braided river system towards a meandering system [17-19] and was accompanied by a concomitant phase of general incision. Very soon after, a forested landscape developed, diminishing the water discharge (Bogemans et al). The channels were gradually filled in with peat and organic to peaty clay. The sea-level rise during the Holocene had the indirect consequence of raising the groundwater level, which also stimulated and had a positive impact on the peat growth [17]. Downstream of Antwerp, tidal influence has been registered since 2500-1600 years BP. From 1100-1000 years BP [20], the lower Scheldt area became an estuary, establishing the deposition of large series of clay 
and sand in the area. The construction of the dikes brought an end to this sedimentation except during flooding conditions.

\subsubsection{Quaternary Deposits}

The thickness of the Quaternary deposits varies from $5 \mathrm{~m}$ in the centre of Antwerp, to $15-20 \mathrm{~m}$ in the harbour area (Figure 2). The Quaternary sedimentation in the Scheldt polders occurred in a dynamic environment, implying important lateral variations even within the same unit. This situation makes this studied area very complex when investigated in detail. However, in this study, the focus is on the settlement capacity of the sediments; therefore, the current description is based on a lithological description. The granulometry and the presence of peat are certainly the main factors that need to be considered when assessing the geomechanical compaction of the sediments. A synthetic table (Table 1) summarises the geological formation names of the Quaternary versus their age and the observed lithologies.

Table 1. List of the different Quaternary geological formations encountered around Antwerp and the top of the first Tertiary geological formation. The descriptions of the following quaternary units are based on the information given on the website of the National Commission for Stratigraphy Belgium. It is based on [18] and has been updated in 2017.

\begin{tabular}{|c|c|c|c|}
\hline Formation & Period & Epoch & Description/Lithology \\
\hline Vlaanderen & Quaternary & Holocene & $\begin{array}{c}\text { Coarse tidal channel sand, fine wadden sand and tidal flat clay with peat } \\
\text { horizons }\end{array}$ \\
\hline Arenberg & Quaternary & Holocene & Fine-grained alluvial deposits with peat horizons \\
\hline Eeklo & Quaternary & Upper Pleistocene & $\begin{array}{l}\text { Alluvial and fluvio-periglacial sands with loamy layers and gravels in the infill } \\
\text { of the Flemish Valley and the Coastal Plain }\end{array}$ \\
\hline Gent & Quatern & Upper Pleist & Aeolian fine sand \\
\hline Ravels & Quaternary & Lower Pleistocene & Fine sand with peaty clay layers deposited in a fluviatile environment \\
\hline Weelde & Quaternary & Lower Pleistocene & Alternation of clayey and sandy deposits \\
\hline
\end{tabular}

\subsubsection{Tertiary (Paleogene-Neogene) Deposits}

More than $400 \mathrm{~m}$ of Tertiary monoclinal layers gently dipping towards the NW are overlain by Quaternary sediments. The average slope of these Tertiary layers is about $5 \mathrm{~m} / \mathrm{km}$. In this area (Figure 3), the oldest Paleogene formation corresponds to the Maldegem Formation (mostly Bartonian, $\pm 40 \mathrm{Ma}$ ). The Formation of Merksplas is the youngest (Neogene, Pliocene-Early-Pleistocene) Tertiary formation present in the region. The different Tertiary formations present in the ROI are described (Table 2) with their name for each geological formation, their age, their lithology and their approximate thickness in the area. The thicknesses given here differ from those published by [21] as the values reported hereafter were calculated from the 3D geological model of Flanders [22]. 


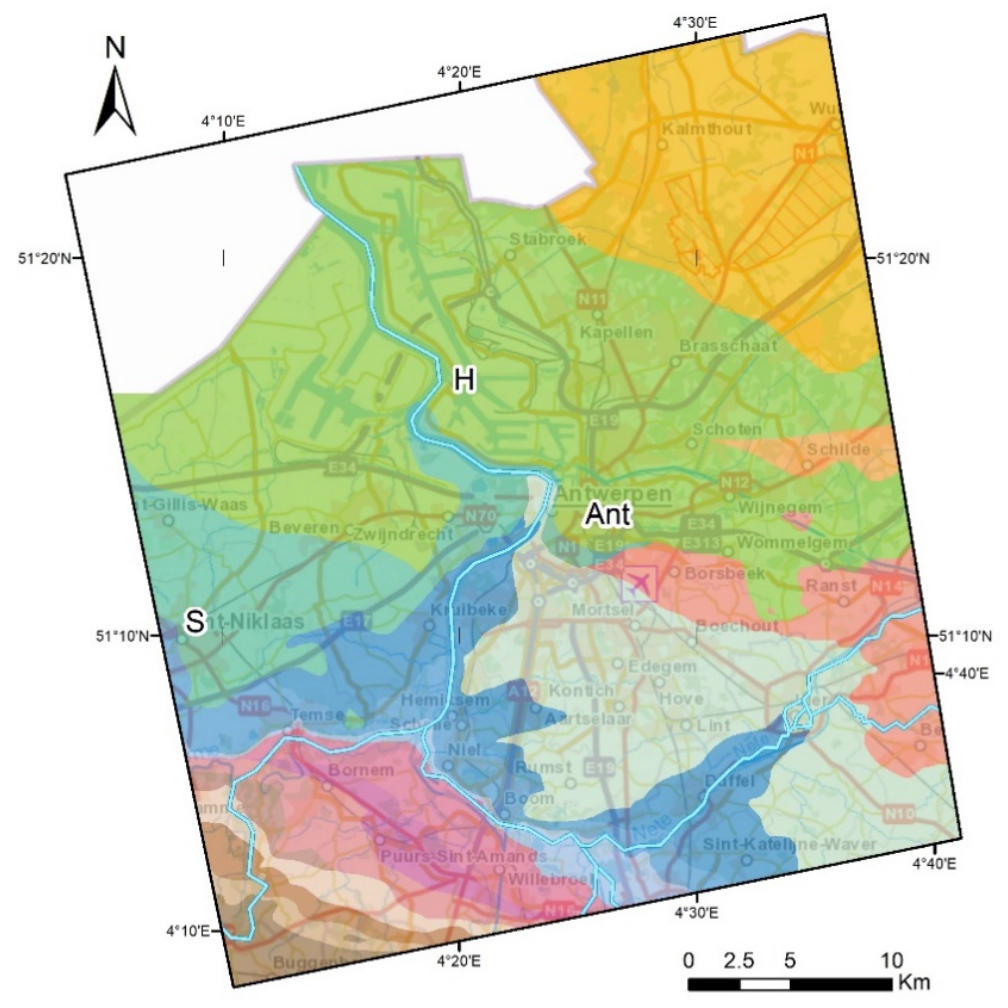

Figure 3. Tertiary geological map of the ROI covering the Antwerp and the Scheldt river area (extracted and modified from the digital version of the Tertiary geological map [23]-colour legend given in Table 2) Ant: Antwerp city centre, H: Harbour of Antwerp, S: Sint-Niklaas. Background NGI topographic map.

Table 2. Listing of each Tertiary geological formation with their age, lithological content and thickness based on [22,24] present in the studied area.

\begin{tabular}{|c|c|c|c|}
\hline Formation & Age & Description & Thickness (m) \\
\hline Merksplas & Pliocene & $\begin{array}{l}\text { Grey medium to coarse sand, with glauconite and wood fragments. } \\
\text { Containing shell fragments in the lower part and occasionally gravels. }\end{array}$ & On average, 5 \\
\hline Lillo & Pliocene & $\begin{array}{l}\text { Grey, grey brown and light grey brown shelly and, clayey in the lower part and } \\
\text { with several shell layers; in the upper part gradual decrease in the clay content. }\end{array}$ & 2.5 to 10 \\
\hline Kattendijk & early Pliocene & Dark grey to green grey, fine to medium fine, glauconitic sand, slightly clayey. & 5 to 10 \\
\hline Diest & Late Miocene & $\begin{array}{l}\text { Grey green to brownish, mostly coarse, locally clayey, glauconitic sand often } \\
\text { with sandstone layers; mainly without fossils. }\end{array}$ & 10 to 25 \\
\hline Berchem & Miocene & $\begin{array}{l}\text { Green to blackish, fine to medium sand, often slightly clayey, high glauconitic } \\
\text { content; rich in shells. }\end{array}$ & 15 to 25 \\
\hline Boom & Oligocene & Grey silty clay or clayey silt, with pyrite and glauconite in the siltiest horizons. & Up to70 \\
\hline Zelzate & $\begin{array}{l}\text { late Eocene to } \\
\text { early Oligocene }\end{array}$ & $\begin{array}{l}\text { Dark grey, moderately fine, silty sand, glauconitic and micaceous, with } \\
\text { intercalations of thick lenses of grey clay. Covered by dark green, sandy clay. }\end{array}$ & 0 to 27 \\
\hline Maldegem & Eocene & Succession of clays and sands with a gradual increase in glauconitic content. & On average 50 \\
\hline
\end{tabular}

\section{Methodology}

The PSInSAR analyses over the Antwerp area have been achieved using mainly two software suites: the historical ERS-ENVISAT data were processed using Doris-StaMPS [25,26] while the recent Sentinel 1A (S1) data were done using SARPROZ [27]. In general, Belgium is particularly well covered by the ESA SAR imagery whatever the acquisition geometry. Therefore, in this area, about 70 SAR images were processed for each satellite time-interval ensuring reliable long time series (Table 3). The ERS and ENVISAT 
datasets are characterized by a large spatial normal baseline distribution that does not exceed the $2000 \mathrm{~m}$ of the orbital tube. The graphs for ERS and ENVISAT (Figure 3) present a very dense and long temporal sequence with the master image well centred inside the studied time interval. The S1 dataset corresponds to a reduced spatial normal baseline distribution covering an orbital tube range of almost $300 \mathrm{~m}$ and a very dense temporal sequence with the master image well positioned in the middle of the studied time interval (Figure 4). However, there is a gap of 6 years between the last ENVISAT SAR image acquisition due to its failure and the first Sentinel 1 data used. The first two years of S1 were not used in this processing to benefit from a larger spatial coverage related to an ongoing processing project covering the entire Belgium country. The acquisition parameters (area acquired for the same track) for the period 2014-2016 is different from the following period, which makes it difficult to process over a large area. For ERS and ENVISAT, the data processed during this work are in L0-RAW format. The Single Look Complex (SLC) were obtained using the ROI-PAC package [28]. During the processing, the external digital elevation model (DEM) data from the Shuttle Radar Topography Mission (SRTM 3-arc second) with $90 \mathrm{~m}$ horizontal resolution [29] was used to remove the topographic component of the interferometric phase. The selected master images for ERS descending, ENVISAT descending and S1 ascending were acquired on 18 July 1998, 15 August 2007 and 27 July 2017, respectively. The average acquisition time sampling scheme uses data with a long period of 35 days for ERS and ENVISAT and a shorter period of 12 days for S1. After the processing, only the PS characterized by a temporal coherence greater than 0.7 have been selected, a common value in radar interferometry studies [30,31].
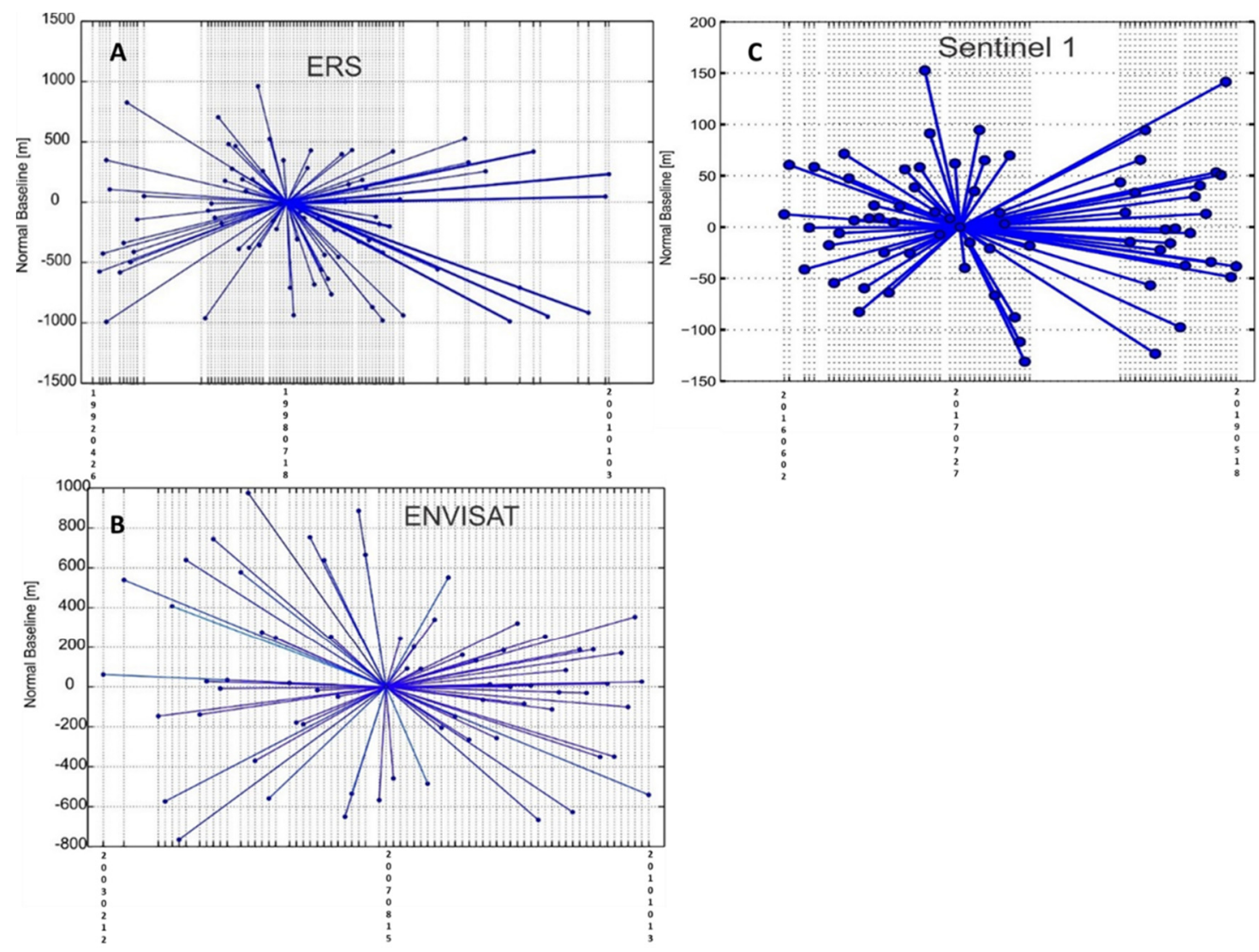

Figure 4. Normal Baselines in $m$ versus Time acquisition graphs for the three SAR image datasets related to (A). ERS, (B). ENVISAT and (C). Sentinel 1. 
Table 3. Characteristics of the SAR image datasets used for the Antwerp area.

\begin{tabular}{ccccccc}
\hline Satellite & Track & Pass & $\begin{array}{c}\text { Number } \\
\text { of Scenes }\end{array}$ & $\begin{array}{c}\text { Acquisition } \\
\text { Period }\end{array}$ & Master & Processing Software \\
\hline ERS 1/2 & 423 & Descending & 67 & $1992-2001$ & 18 July 1998 & ROI_PAC, Doris, StaMPS \\
ENVISAT & 423 & Descending & 73 & $2003-2010$ & 15 August 2007 & ROI_PAC, Doris, StaMPS \\
S1 & Path 88 track 163 Swath 1 & Ascending & 69 & 2016-2019 & 27 July 2017 & SARPROZ \\
\hline
\end{tabular}

\section{Results}

The processing results for the three SAR imagery datasets for both the harbour area and the city centre are reported in the form of histograms, one for each satellite (Figure 5). These histograms combine the number of PS and the average LOS velocity subdivided into 9 successive classes from negative LOS velocity values (i.e., subsidence) on the left towards positive LOS velocities (i.e., uplift) on the right. The light asymmetrical morphology towards the left for each histogram highlights the contribution of more PS having negative LOS velocity values. The average LOS velocities for the Antwerp centre and harbour areas are reported for ERS, ENVISAT and S1, respectively, on Table 4. The data include also, for each satellite datasets, the number of PS used to calculate these averages. The average LOS velocity values in the Antwerp harbour $(\mathrm{H})$ are globally negative $(<-2 \mathrm{~mm} /$ year $)$ while in the Antwerp city centre (Ant), they are on average near zero ( 0 mm/year).
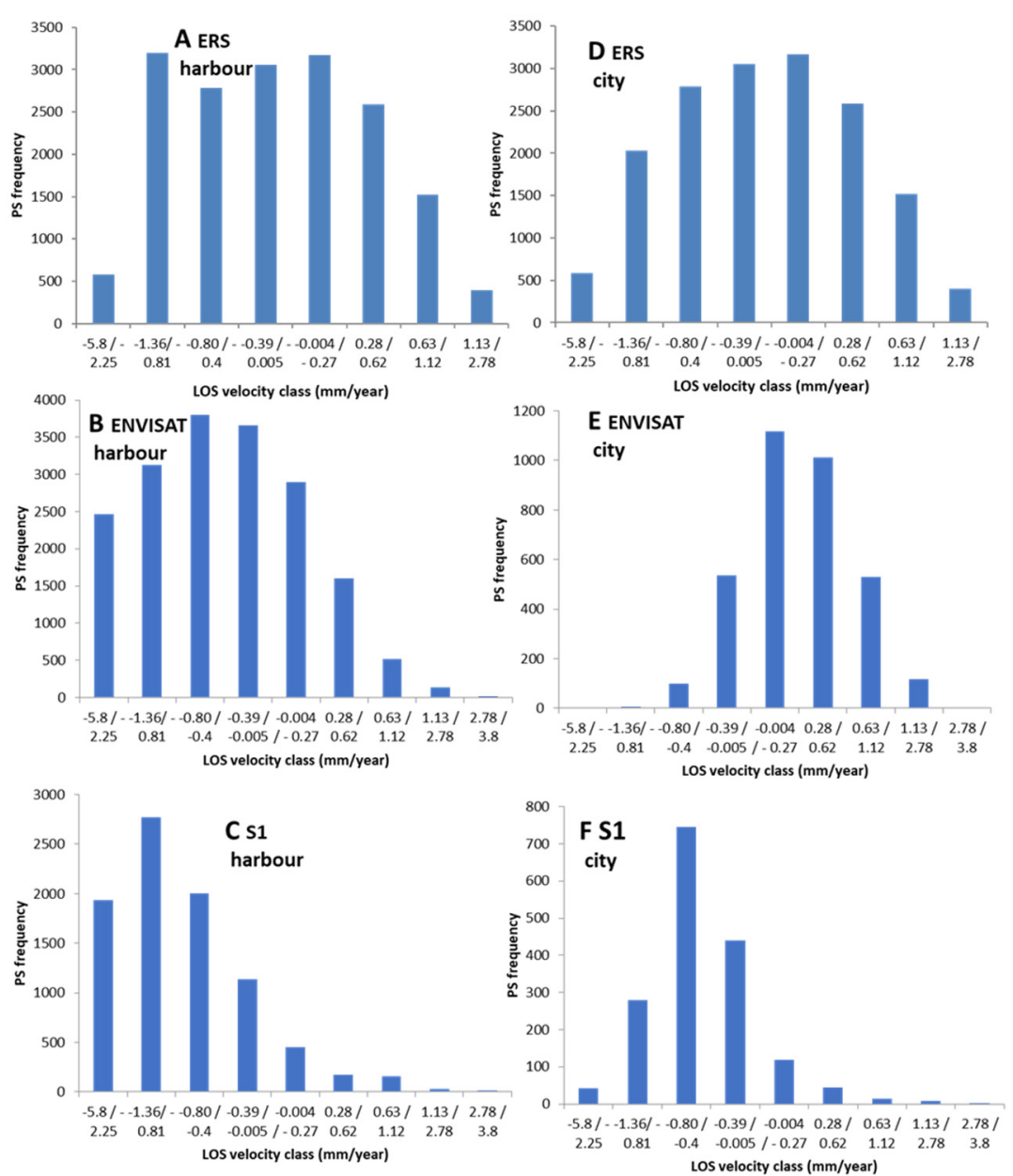

Figure 5. Histograms based on the annual average LOS velocities (in mm/year) of the PS in the Antwerp harbour and city areas, respectively, for ERS (A,D); ENVISAT (B,E); S1 (C,F). 
Table 4. Average velocities and number of retrieved PS for the Antwerp centre and harbour areas both for ERS, ENVISAT and S1 datasets.

\begin{tabular}{|c|c|c|c|c|c|c|}
\hline Location & $\begin{array}{c}\text { Avg LOS } \\
\text { Velocity ERS } \\
(1992-2001) \\
\text { (mm/year) }\end{array}$ & $\begin{array}{c}\text { PS Count } \\
\text { ERS } \\
\text { (1992-2001) }\end{array}$ & $\begin{array}{c}\text { Avg LOS Velocity } \\
\text { ENVISAT } \\
(2003-2010) \\
(\mathrm{mm} / \text { year })\end{array}$ & $\begin{array}{c}\text { PS Count } \\
\text { ENVISAT } \\
(2003-2010)\end{array}$ & $\begin{array}{l}\text { Avg LOS } \\
\text { Velocity S1 } \\
\text { (2016-2019) } \\
\text { (mm/year) }\end{array}$ & $\begin{array}{c}\text { PS Count S1 } \\
(2016-2019)\end{array}$ \\
\hline Antwerp & 0.002 & 4518 & -0.06 & 3420 & -0.6 & 1699 \\
\hline Antwerp harbour & -0.83 & 535 & -2.71 & 718 & -1.62 & 1265 \\
\hline
\end{tabular}

Two areas in the ROI show a lack of PS in each dataset. It corresponds to the Verdronken Land van Saeftinghe (V) and De Zoom-Kalmthoutse Heide (Z), respectively, (Figure 6). These two regions partly located in The Netherlands and crossing the borders between the two countries are natural parks and, thus, have not much human infrastructures for reflecting the radar signal. Otherwise, the large coverage of the PS in the ROI indicates that this area has a high density of urbanization and subsequently a high population density.
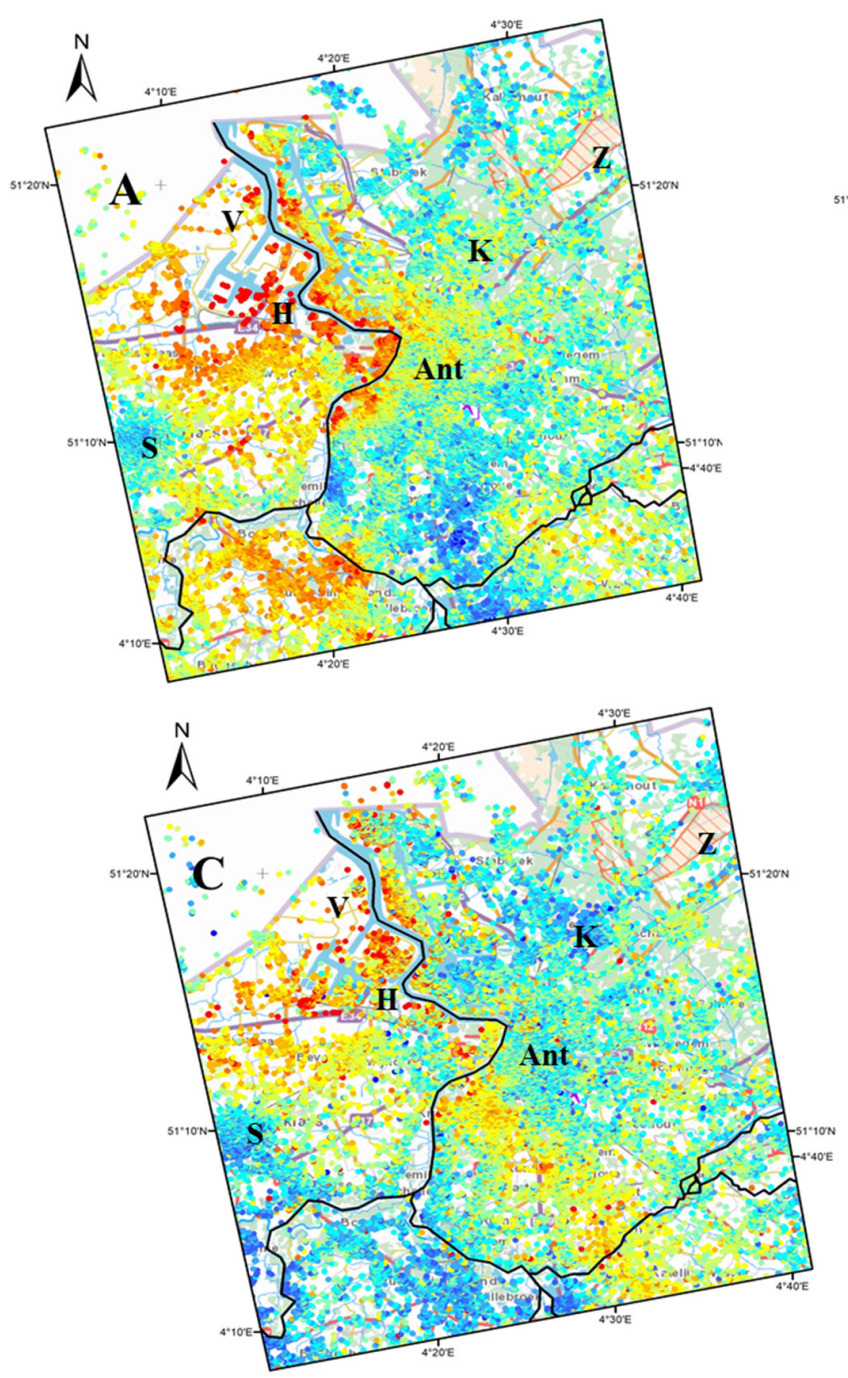

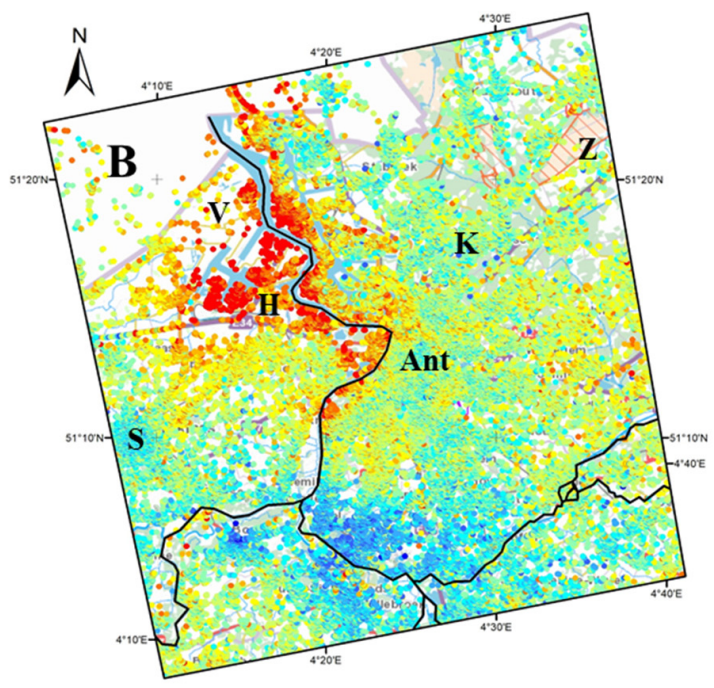

Annual average velocity $(\mathrm{mm} / \mathrm{year})$

$$
\begin{array}{r}
-5.80--2.25 \\
-2.24--1.36 \\
-1.35--0.81 \\
-0.80--0.39 \\
-0.38--0.05 \\
-0.04-0.27 \\
0.28-0.62
\end{array}
$$$$
\text { - } \quad 0.63-1.12
$$$$
\text { - } 1.13-1.83
$$$$
\text { - } 1.84-3.80
$$

Figure 6. Colour classification (red to blue filled dots) based on the average annual LOS velocities of the PS points (in mm/year) for ERS (A); ENVISAT (B) and S1 (C). Negative values (red/orange) indicate areas of subsidence, while positive values (blue) represent uplifting conditions. $(\mathrm{H})$ for Antwerp harbour area, (Ant) for Antwerp city centre, (S) for Sint-Niklaas, (K) for Kapellen, (V) Verdronken Land van Saeftinghe and (Z) De Zoom-Kalmthoutse Heide area. Background NGI topographic map. 
During the ERS period (1992-2001), the LOS velocities range from -5.8 to $2.41 \mathrm{~mm} /$ year (Figure 6A). A clear, distinct area haracterized by negative annual average LOS velocities suggest a subsidence motion located along the Scheldt river and the harbour facilities on both sides of the Scheldt river. The western side of the river is haracterized by a $20 \mathrm{~km}$ wide area of negative LOS velocity values. On the eastern side of the river, the lowest velocity values are concentrated inside a narrow area bordering the riverbank. At the extreme SW of the image, in Sint-Niklaas (S), the area shows positive average LOS velocity values indicating that this region is probably uplifting due to groundwater rebound as already highlighted in other areas in Belgium (e.g., around the cities of Merchtem and Londerzeel [31]. The city centre of Antwerp (Ant) is essentially coloured in greenish and, thus, has average annual LOS velocities around $0 \mathrm{~mm} /$ year.

During the ENVISAT period (2003-2010) (Figure 6B), the negative annual LOS velocity values are also located along the banks of the Scheldt river and on the harbour facilities. However, the annual LOS velocity values are ranging from -5.1 to $3.2 \mathrm{~mm} /$ year. The spatial extension of the strongest negative velocity values in the western part of the river is limited in comparison with the ERS period. In other words, only the river borders and the harbour facilities are concerned by the "fastest" negative annual LOS velocities. The Sint-Niklaas (S) municipality is still characterised by positive LOS velocity values but having lower annual LOS velocity values. Again, the city centre of Antwerp is characterised by very stable LOS velocity values. The other areas of the image are characterized either by slightly positive annual LOS velocity values or by green PS points indicating no ground movements.

For S1 (2016-2019) (Figure 6C), the annual average LOS velocity values range from -4.7 to $3.8 \mathrm{~mm} /$ year. The negative annual LOS velocities are located along the Scheldt river and the harbour facilities with a similar pattern as those observed in the previous period. However, there are fewer PS present in the negative LOS velocity colour classes (red to orange). Significant and positive annual LOS velocity values are still observed in Sint-Niklaas (S) as well as in Kapellen (K), located to the North of Antwerp. Near zero annual LOS velocity values are again observed in the city centre of Antwerp confirming the very stable ground conditions there.

\section{Interpretation and Discussion}

The Antwerp harbour area and the Scheldt valley are mainly characterized by negative annual LOS velocity values during the last 27 years (1992-2019). On the contrary, the city centre of Antwerp located on the eastern side of the Scheldt river is characterized by very stable (near zero) annual LOS velocity values. There is, thus, a need to explain the ground movements observed in the ROI and to determine the different factors influencing them.

\subsection{Harbour of Antwerp}

The Antwerp harbour activities allow the city to rank at the 16th position in the world ports and at the 2nd place in Europe with \pm 200 million tons of goods exchanged and 16,000 boats per year. Before the 16th century, the Antwerp harbour was mainly dedicated to the embarkment for passengers travelling to England and Zeeland. Additionally, wine and goods coming from Germany were routed to England via those facilities. The 16th century marked a major transition and the harbour evolved towards an international position and the boat freight transport increased. It is also the start of the development of the facilities towards the north. The industrial period started at the beginning of the 19th century and after WWII when the Marshal Plan transformed the harbour into the largest chemical hub in Europe. This was possible thanks to another large extension of the harbour facilities towards the north. Since then, the expansion of the facilities grew exponentially thanks to the construction of the largest lock in the world, giant docks in the western side of the riverbanks and the deepening of the Scheldt river allowing the navigation of the largest container vessels. Figure 7 shows not only the latest developments of the harbour areas that occurred during the time span of the satellite observations but also the future ones. The year 1982 was the starting time of the development of the facilities located on the western side of the Scheldt river. 

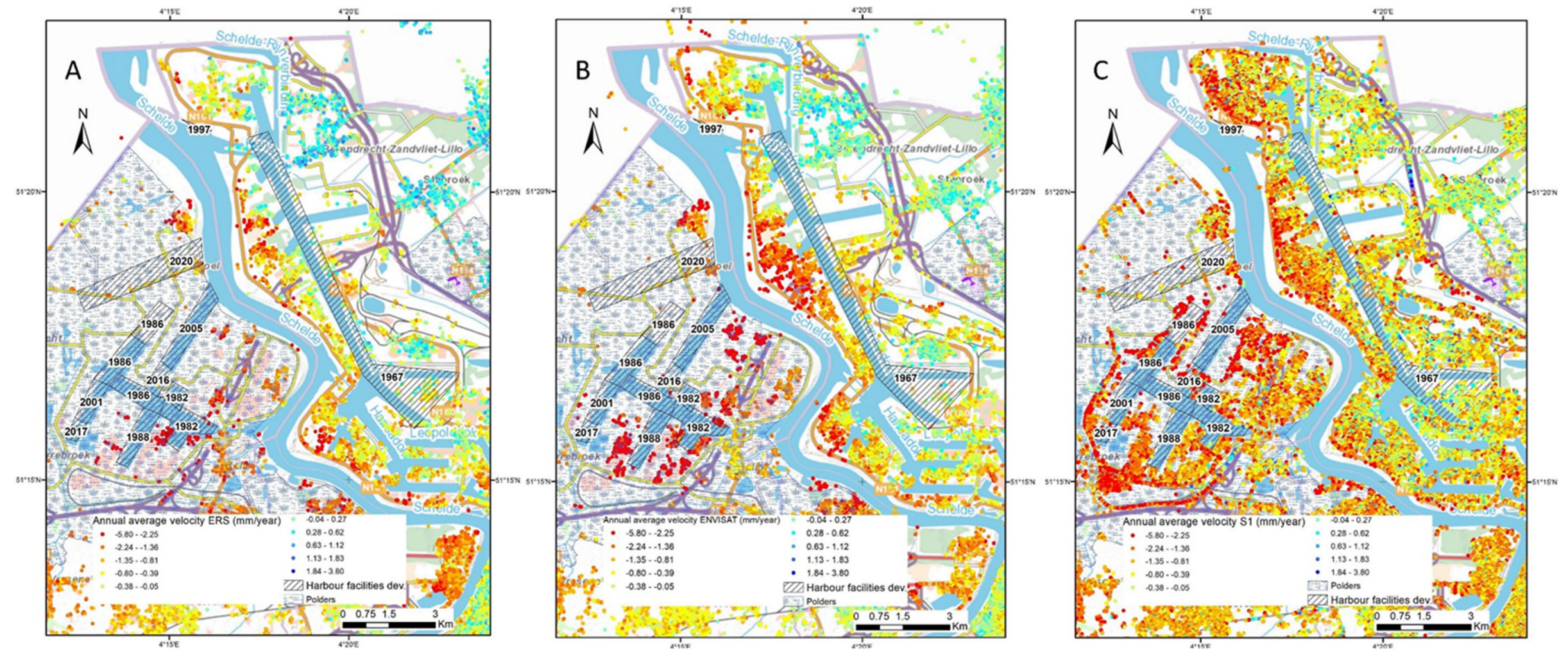

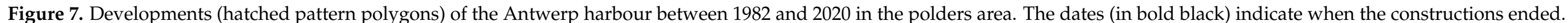

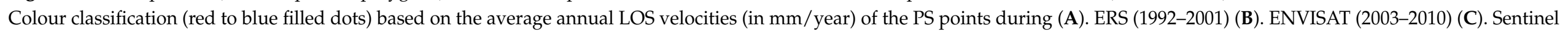
S1 (2016-2019) time periods. Background NGI topographic-map. 
Among the 45,000 ha that the western part of the Scheldt covered in 1800, around 15,000 ha are dedicated today to the Antwerp port activities [32]. These new built zones are concentrated in an area characterized by polders, which have, by definition, an elevation below the average sea level. To allow the construction of the docks and embankments, the area was first maintained dried [32] to install the concrete foundations of the constructions and several meters of landfills were added to raise the original topography above the sea level (Figure 8). The sedimentary materials used as landfills came mainly from dredging sediments from the Scheldt river. They are, thus, mainly composed of heterogeneous layers of sands, silts, clays and peats with, in some places, a few accumulations of broken carbonate shells depending on the primary location of the sediments deposited in the inner or outer side of the meanders. The evolution of the harbour facilities (Figure 7) is marked by the creation during the last few decades of new docks (from 1982 up to now). The last one planned for 2020 is also reported on the NW area (left bank of the Scheldt river).

The analysis of Figure 6A-C shows that most of the construction of the facilities occurred 5 to 10 years before the beginning of the ERS satellite acquisitions (i.e., 1992). Most of the PS located on the western side of the Scheldt river are characterised by negative annual average LOS velocity values ranging between -1.36 to $-5.80 \mathrm{~mm}$ /year showing that this area is clearly affected by land subsidence since the ERS observations until S1. On the other side the strongest negative ones are concentrated in the embankments zone. The delimited docks zone defined for 2020 and the absence of PS indicate that heavy engineering works are probably occurring in the NW.

According to our analyses of the available geological data and the model that will be presented hereafter, the land subsidence bowl here along the Scheldt river (western side) is due to the combination of several factors. The latter resulted in a land subsidence phenomenon observed continuously by the extracted PS data during the three successive satellite datasets (i.e., 27 years). Firstly, the studied area is in the alluvial plain of the Scheldt river and thus naturally composed of recent (Holocene) loose and unconsolidated sediments. Those Holocene estuarine deposits are made of sand, silt and clay with organic materials and peat layers [33]. Such unconsolidated deposits have a high potential for being affected by strong compaction. Secondly, as already mentioned, on top of the alluvial plain deposits, $6 \mathrm{~m}$ on average of landfills were added (Figure 8). The landfills themselves are composed mostly by the same deposits that were dredged out the estuarine. The landfills are, thus, increasing the load on the natural Holocene sedimentary deposits and, therefore, contributing to the subsidence. Indeed, the most negative PS velocities are located on areas corresponding to a maximum thickness of the landfills. Thirdly, the industrial harbour facilities are also responsible for increasing the load and, thus, implying more settlement. The measured subsidence deduced from the PS data is, therefore, probably due to the conjugated settlement of both the alluvial plain deposits and the landfills.

On the other side of the river (northern and eastern areas, Figure 7; Figure 8), along the embankments, a high density of PS is also highlighting negative average annual LOS velocity values suggesting also a land subsidence phenomenon. The observed land subsidence is thus most likely due to a combination of (i) an ongoing consolidation process induced by an average thickness of $8 \mathrm{~m}$ of landfills installed before the monitoring of ground movements by InSAR techniques and (ii) the construction of buildings associated to the development of the Antwerp port installations on the natural alluvial plain sediments along the right bank of the Scheldt river. 

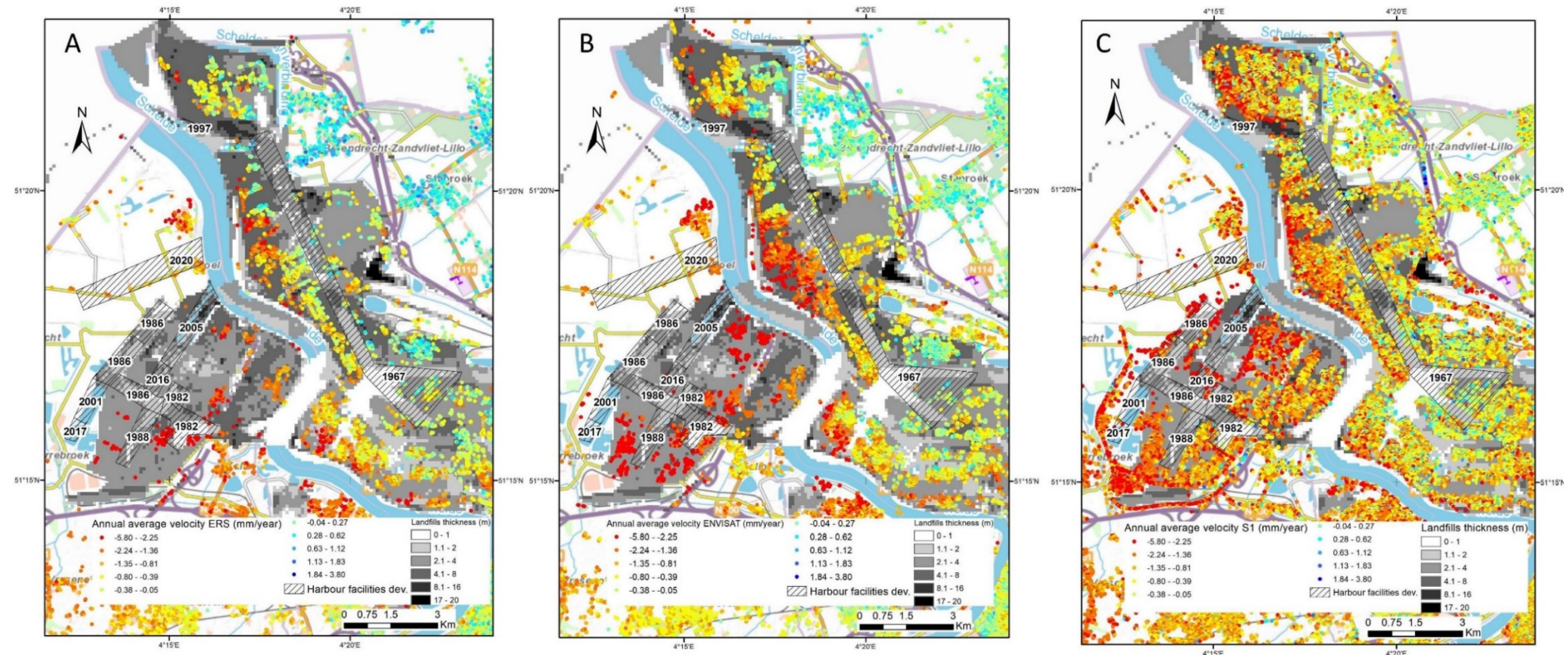

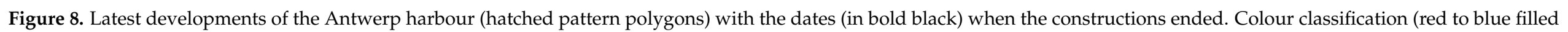

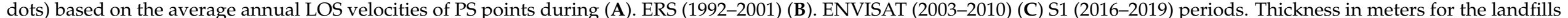
(white to black filled polygons). Background IGN topographic-map. 


\subsection{City Centre of Antwerp}

Located in the NE of Flanders, the city of Antwerp occupies a strategic position thanks to its harbour facilities. Antwerp is the second largest metropolitan area in Belgium with over 1.2 million inhabitants. The population of the city itself with $\pm 500,000$ inhabitants is the third city of Belgium in area with $200 \mathrm{~km}^{2}$ [34].

On average the annual LOS velocity values for the city centre of Antwerp during the three SAR image datasets are almost equal to zero (Table 4), which is different from the ground movements observed in the harbour and facilities areas (negative LOS velocity values, i.e., land subsidence). Although the city centre is bordered to the west by the Scheldt river and its alluvial quaternary sediments, the sedimentary sequence underneath the city centre of Antwerp is different. The city lies on several Quaternary and Tertiary formations. The thickest sequence corresponds to the Berchem Formation (Miocene, Neogene) and more precisely to the sands of the Antwerpen Member composed of marine coarse sands with shell debris $[35,36]$.

Two representative boreholes characterizing the sedimentary first layers directly underneath the harbour area and the city centre of Antwerp were selected to illustrate the geological differences between those zones and their impact on the observed ground movements highlighted by the PSI analysis. The drillings GEO 017093-hb6 and GEO95/116-CKW22 located, respectively, in the city centre and in the harbour area are precisely reported on a topographic map of the Antwerp area (Figure 9). A summary of the different sedimentary layers, their lithologies, depths and assigned ages are presented in two tables (Table 5; Table 6). The borehole GEO-95/116-CKW22 is in the harbour area (coordinates X:142356, Y: 220,442 in EPSG 31370). This drilling located near Doel is a reference illustrating the main typical lithologies that compose the landfills and the natural sedimentary sequence deposited in the western Scheldt polders.

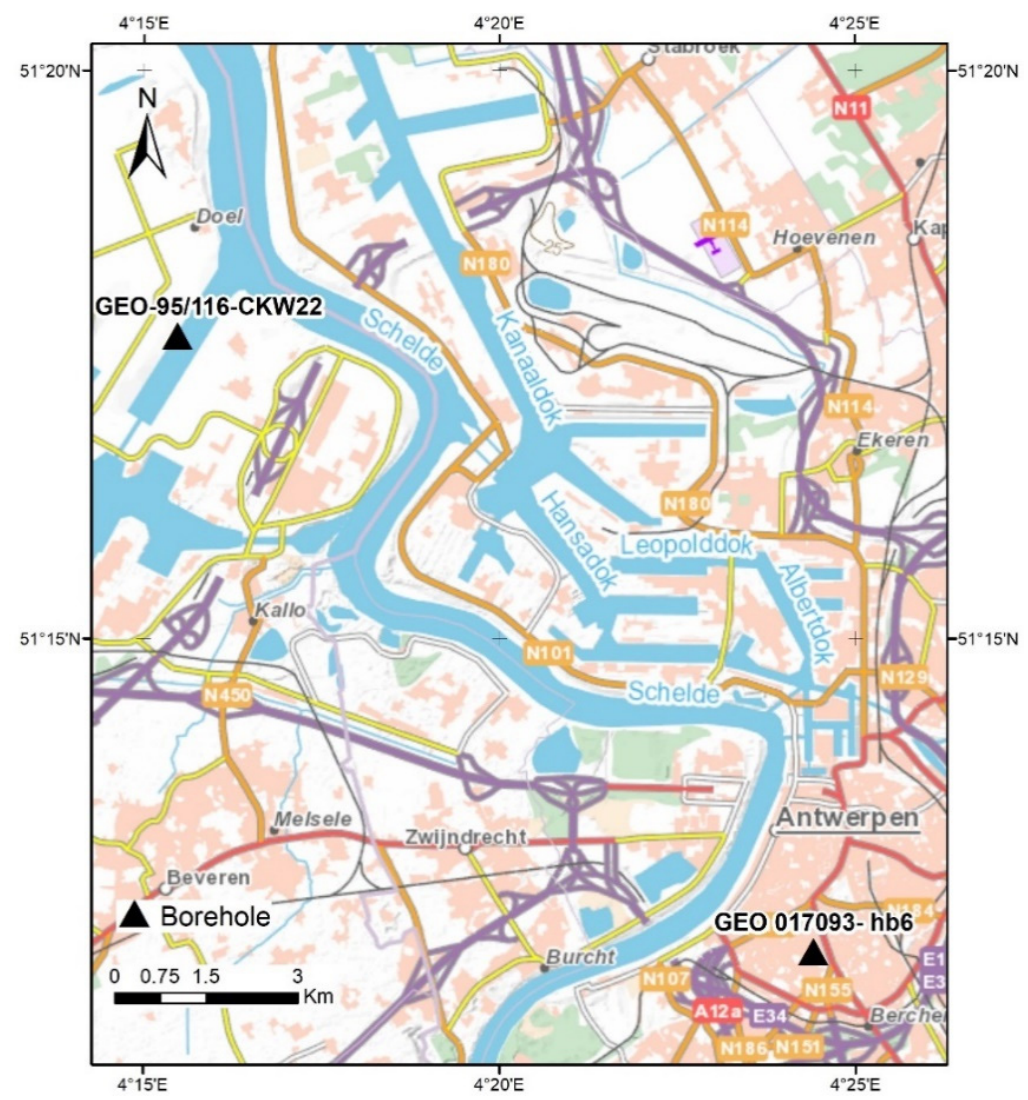

Figure 9. Location of the boreholes GEO 017093- hb6 and GEO-95/116-CKW22. Background IGN topographic map. 
The average ground stability or at least the near zero annual LOS velocity values observed in the city centre of Antwerp are related to the following two main elements.

Firstly, the sedimentary layers underneath the city centre of Antwerp consists in aeolian sands-silts of the late Pleistocene (Gent Formation). Those sediments of the Gent Formation of Pleistocene age underneath the Antwerp city centre are older than the Holocene sediments (Vlaanderen and Arenberg Formations) encountered below the harbour and have been consolidated during thousands of years (since the end of the Pleistocene that ended 11,700 years ago) before the construction of the city. The compaction of these Pleistocene sediments under their self-weight should be almost completed today due to both the duration of the compaction leading to a probably complete consolidation process, and the nature of these sediments (i.e., sand deposits have a low compressibility). The spatial extension of the Holocene deposits (Figure 10) reveals clearly that these deposits are only present in in the western part of the city centre of Antwerp in a narrow band along the Scheldt river.

Secondly, in Antwerp city, the members of Berchem Formation are made up of medium to coarse sands and are directly found under the Quaternary (Pleistocene) deposits. The age gap of about 20 Ma between the Berchem Formation and the Quaternary deposits implies that the sediments of the Berchem Formation have been already consolidated. Additionally, in the Geomechanical map of Antwerp 15.3.1 Petroleumhaven [37], there is a factor $10^{2}$ between the compression index of the sands and the silty clay sediments. This implies that the sand deposits are by far less compressible than the other deposits and therefore that the PS in the city centre does not show any subsidence.

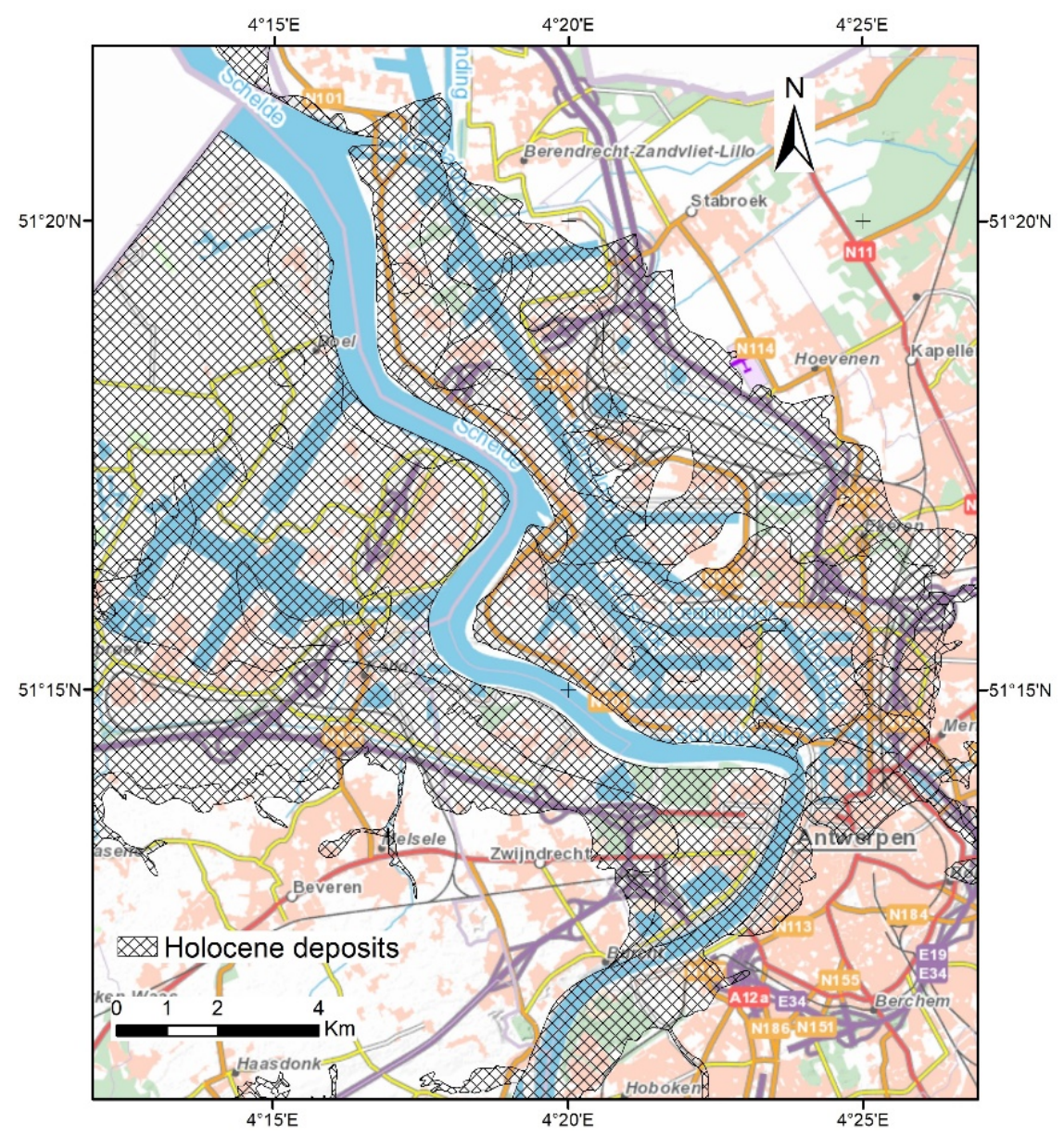

Figure 10. Extension of the Holocene deposits [34]. Background IGN topographic map. 
Table 5. Quaternary and Tertiary formations, age and lithologies described in the borehole GEO-95/116-CKW22 located in the harbour area (X:142356, Y: 220,442 in EPSG 31370).

\begin{tabular}{|c|c|c|c|c|}
\hline $\begin{array}{l}\text { Depth Interval } \\
\text { (from Surface) }\end{array}$ & Formation or Type & Period & Epoch & Lithology \\
\hline $0-4.5 \mathrm{~m}$ & "Landfills" & Quaternary & NA & Sand, Silt, Clay, Peat \\
\hline $4.5-12.25 \mathrm{~m}$ & $\begin{array}{c}\text { Landfills } /+ \text { Vlaanderen } \\
\text { and Arenberg } \\
\text { Formations }\end{array}$ & Quaternary & NA/Holocene & \\
\hline $12.25-21 \mathrm{~m}$ & Lillo Formation & Neogene (Tertiary) & Pliocene & Clayey and shelly silty sand \\
\hline $21-25 \mathrm{~m}$ & Kattendijk Formation & Neogene (Tertiary) & early Pliocene & $\begin{array}{l}\text { Fine to medium glauconitic sand } \\
\text { Medium to coarse (Antwerp }\end{array}$ \\
\hline $25-38.95 \mathrm{~m}$ & Berchem Formation & Neogene (Tertiary) & Miocene & $\begin{array}{l}\text { members) sands, slightly clayey and } \\
\text { enriched in glauconite and shells }\end{array}$ \\
\hline $38.95-42 \mathrm{~m}$ & Boom Formation & Paleogene (Tertiary) & Oligocene & Grey silty clay \\
\hline
\end{tabular}

Table 6. Quaternary and Tertiary formations, age and lithologies deduced from the borehole GEO 017093- hb6 located in the city centre of Antwerp (X:152750, Y: 210,330 in EPSG 31370).

\begin{tabular}{|c|c|c|c|c|}
\hline $\begin{array}{l}\text { Depth Interval } \\
\text { (from Surface) }\end{array}$ & $\begin{array}{c}\text { Formation or } \\
\text { Type }\end{array}$ & Period & Epoch & Lithology \\
\hline $0-0.5 \mathrm{~m}$ & \multirow{3}{*}{$\begin{array}{c}\text { Disturbed soil } \\
\text { Gent Formation } \\
\text { Berchem } \\
\text { Formation }\end{array}$} & \multirow{3}{*}{$\begin{array}{l}\text { Quaternary } \\
\text { Quaternary } \\
\text { Neogene } \\
\text { (Tertiary) }\end{array}$} & \multirow{3}{*}{$\begin{array}{l}\text { Pleistocene } \\
\text { Miocene }\end{array}$} & Reworked materials \\
\hline $0-2.5 \mathrm{~m}$ & & & & Reworked materials (bricks...), aeolian sand and silt \\
\hline $2.5-10 \mathrm{~m}$ & & & & $\begin{array}{c}\text { Fine to medium fine sands, slightly clayey and } \\
\text { enriched in glauconite and shells }\end{array}$ \\
\hline
\end{tabular}

The land subsidence areas revealed by PSInSAR data is globally controlled by the extension of the Holocene deposits along the Scheldt embankments and their spatial distribution along the entire area of the harbour facilities extending both westward and northward along the alluvial plain of the Scheldt river (Figure 10). Three GPS stations are present in the studied area for which the vertical velocity was calculated based on the available time series, 2013-2019 for ANTW, 2002-2007 for KALL and 2012-2021 for Beza (data from the Belgian National Geographic Institute, Royal Observatory of Belgium and Flemish Positioning system, FLEPOS). The vertical velocities of the three GPS stations KALL, ANTW and Beza (Figure 11) confirm the observations made using the PSInSAR data and the differences between the city centre and the harbour. The GPS stations KALL and Beza located in the harbour have negative vertical velocities that are strongest than the velocity of the ANTW station located in the city centre. The GPS vertical velocities of the stations located in the harbour are globally a few $\mathrm{mm}$ /year lower in absolute value than the PSInSAR measurements. This require further investigations but could be related to the specificity of the buildings chosen to install the GPS stations. Nevertheless, the difference of velocity is well present between the harbour and the city centre, and confirms our model. 


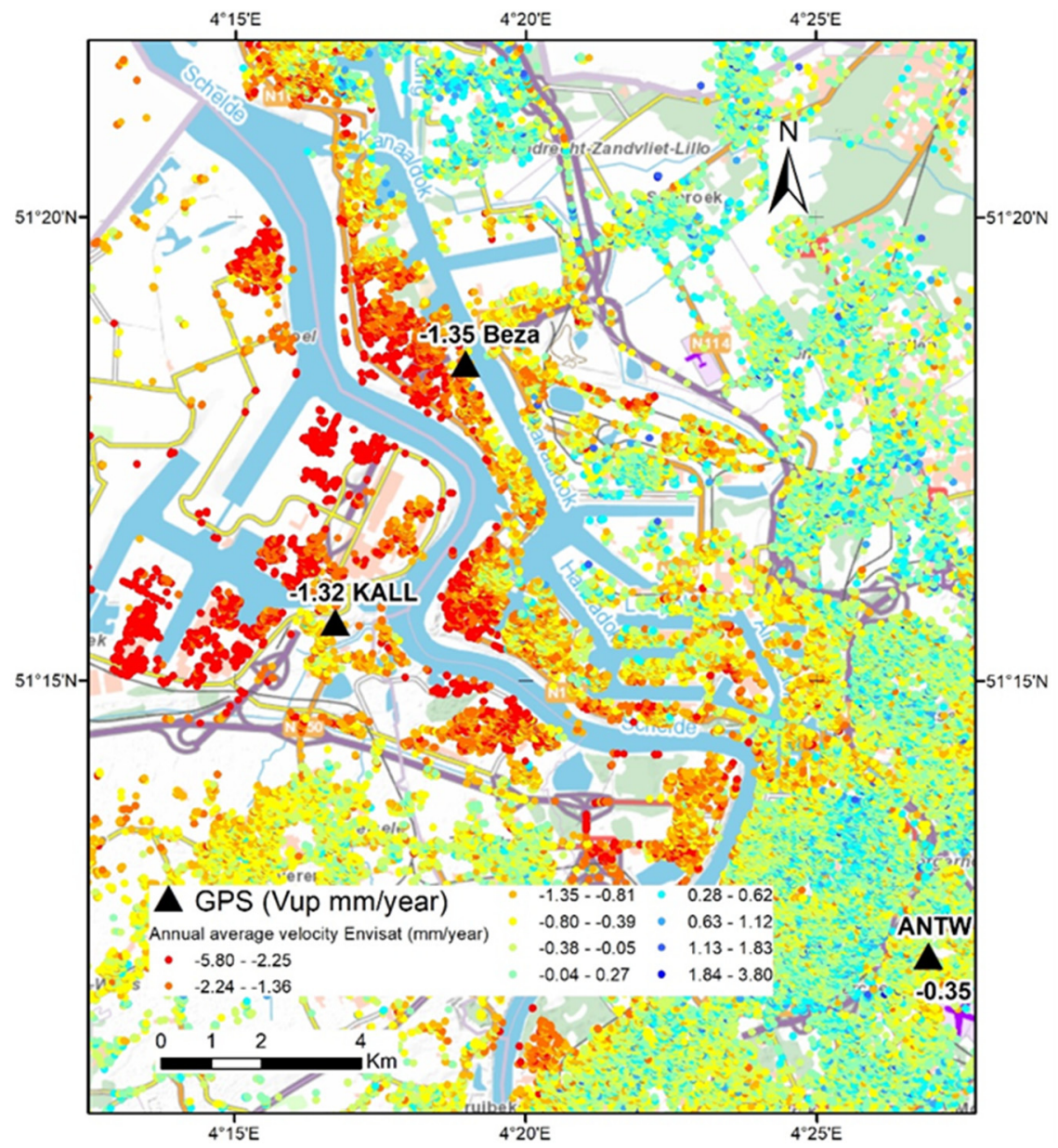

Figure 11. Colour classification (red to blue filled dots) based on the average annual LOS velocities of the PS points (in mm/year) for ENVISAT showing the harbour and the city centre of Antwerp. Location and vertical velocity, Vup (in mm/year) of the GPS stations. Background IGN topographic map.

\section{Conclusions}

In this paper, PSInSAR datasets from different sensors operating in C-band (ERS1/2, ENVISAT, S1) during the time period extending from 1992 to 2019 are presented to describe the temporal and spatial evolution of the land subsidence affecting the region of Antwerp. The latter is highlighted by an average annual LOS velocity of about $-3.4 \mathrm{~mm} /$ year during the years 1992-2001 (ERS1/2 datasets), followed by an average annual LOS velocity of about $-2.71 \mathrm{~mm} /$ year and $-2.11 \mathrm{~mm} /$ year, respectively, during the years 2003-2010 (ENVISAT) and 2016-2019 (S1). The SAR imagery data indicate a progressive decrease in the average annual velocities on a global scale independently of important local variations in different districts along the Scheldt river. The land subsidence revealed along the embankments of the Scheldt river is associated to a sedimentary sequence composed by a heterogeneous series of quaternary fluvial, tidal, aeolian and slope deposits. The extensions and developments of the harbour facilities on the alluvial plain of the Scheldt river are intimately linked to the presence of landfills (Holocene fluvial and tidal sediments) distributed on the entire area affected by land subsidence. The thicknesses of these landfills range from 0 to $20 \mathrm{~m}$. The spatial extension of the land subsidence is directly linked to the presence of thick landfills cover above natural Holocene sediments. On the contrary, the old historic centre of Antwerp is not affected by negative LOS velocities indicating stable ground conditions throughout the entire period. The main cause of the absence of ground movements in this area lies in the presence of thick sand deposits both from Pleistocene and Tertiary formations underneath the urbanized area. Such geological deposits are less sensitive to settlements, because of their lithologies (sand is generally 
much less compressible than clay, silt and peat) and their ages (the deposits below Antwerp city are older and so more consolidated). The stable ground conditions in the Antwerp city centre are thus totally linked to the spatial extension of these highly compressible Holocene sediments that are limited to a narrow belt on the western side of the city along the right bank of the Scheldt river. The assumption of subsidence caused by the compaction of Quaternary deposits under (i) their self-weight, (ii) additional loading coming from the installation of thick landfills or (ii) additional loading induced by new superficial infrastructures in the harbour should be verified by predictive numerical simulations. Such simulations would be able to predict the expected settlement rate in the area induced by the human activities (i.e., landfills, construction, etc.) through hydro-mechanical couplings taking place in those geological layers.

The harbour facilities of Antwerp correspond to an area prone to land sinking due to the presence of estuaries/alluvial plain sediments. Such subsidence can become critical for the area. This area should be monitored on a yearly base to follow the spatial extension of the land subsidence bowl and to monitor the effects of new urban projects planned along the Scheldt river.

This research illustrates the capacity of InSAR data to monitor subsidence occurring in estuaries area, with LOS velocities around $-3 \mathrm{~mm} /$ year. The use of the PSInSAR technique provided great benefits in terms of enhanced monitoring capability and spatio temporal data coverage, thanks to the largely available SAR data. The freely available S1 SAR data are promising thanks to their acquisition frequency of 6 days while combining Sentinel $1 \mathrm{~A}$ and B. Additionally, it will be possible by combining the descending and ascending geometries to retrieve the vertical and horizontal components of the LOS velocity. In the future, the possible use of higher resolution SAR images such as TerraSAR-X and Cosmo-SkyMed will permit to better detect and measure the ground subsidence affecting smaller structures. Such monitoring is necessary due to the ongoing climatic warming and sea-level rise provoking more flooding events in the future with an increased landward contribution of the tides. However, the study highlights that a deep knowledge of the complex geological context of alluvial plains and the historical evolution of the industrialisation of the area are required to interpret the ground movements.

Author Contributions: Conceptualization, P.-Y.D.; Investigation, P.-Y.D., J.W. and X.D.; Supervision, E.P. and X.D.; Writing—original draft, P.-Y.D.; Writing—review \& editing, P.-Y.D., P.G., E.P., J.W. and X.D. All authors have read and agreed to the published version of the manuscript.

Funding: This research received no external funding and was supported by internal funding from the Geological Survey of Belgium and the projects GEPATAR “Geotechnical and Patrimonial Archives Toolbox for Architectural Conservation in Belgium and LASUGEO "monitoring LAnd SUbsidence caused by Groundwater exploitation through gEOdetic measurements" from the Belgian Sciences Policy.

Institutional Review Board Statement: Not applicable.

Informed Consent Statement: Not applicable.

Data Availability Statement: Not applicable.

Acknowledgments: The ERS-1/2, ENVISAT and Sentinel 1 data are provided by ESA. Recomputed ERS 1/2 orbital data were obtained from Delft Institute for Earth-Oriented Space Research TUDelft. The authors would like to thank Thomas Goovaerts for improving an earlier draft of the manuscript, Frieda Bogemans for her expertise in the Quaternary geology of the area and Michiel Dusar for general comments.

Conflicts of Interest: The authors declare no conflict of interest.

\section{References}

1. Hu, R.L.; Yue, Z.Q.; Wang, L.C.; Wang, S.J. Review on Current Status and Challenging Issues of Land Subsidence in China. Eng. Geol. 2004, 76, 65-77. [CrossRef] 
2. Syvitski, J.P.M.; Kettner, A.J.; Overeem, I.; Hutton, E.W.H.; Hannon, M.T.; Brakenridge, G.R.; Day, J.; Vörösmarty, C.; Saito, Y.; Giosan, L.; et al. Sinking Deltas Due to Human Activities. Nat. Geosci. 2009, 2, 681-686. [CrossRef]

3. Kulp, S.A.; Strauss, B.H. New Elevation Data Triple Estimates of Global Vulnerability to Sea-Level Rise and Coastal Flooding. Nat. Commun. 2019, 10, 4844. [CrossRef] [PubMed]

4. Törnqvist, T.E.; Wallace, D.J.; Storms, J.E.; Wallinga, J.; Van Dam, R.L.; Blaauw, M.; Derksen, M.S.; Klerks, C.J.; Meijneken, C.; Snijders, E.M. Mississippi Delta Subsidence Primarily Caused by Compaction of Holocene Strata. Nat. Geosci. 2008, 1, 173-176. [CrossRef]

5. Mazzotti, S.; Lambert, A.; Van der Kooij, M.; Mainville, A. Impact of Anthropogenic Subsidence on Relative Sea-Level Rise in the Fraser River Delta. Geology 2009, 37, 771-774. [CrossRef]

6. Teatini, P.; Tosi, L.; Strozzi, T. Quantitative Evidence That Compaction of Holocene Sediments Drives the Present Land Subsidence of the Po Delta, Italy. J. Geophys. Res. 2011, 116, B08407. [CrossRef]

7. Wang, H.; Wright, T.J.; Yu, Y.; Lin, H.; Jiang, L.; Li, C.; Qiu, G. InSAR Reveals Coastal Subsidence in the Pearl River Delta, China: Coastal Subsidence in the PRD. Geophys. J. Int. 2012, 191, 1119-1128. [CrossRef]

8. Saleh, M.; Becker, M. New Estimation of Nile Delta Subsidence Rates from InSAR and GPS Analysis. Environ. Earth Sci. 2019, 78, 6. [CrossRef]

9. Fiaschi, S.; Fabris, M.; Floris, M.; Achilli, V. Estimation of Land Subsidence in Deltaic Areas through Differential SAR Interferometry: The Po River Delta Case Study (Northeast Italy). Int. J. Remote Sens. 2018, 39, 8724-8745. [CrossRef]

10. Higgins, S. River Delta Subsidence Measured with Interferometric Synthetic Aperture Radar (InSAR); ProQuest LLC.: Ann Arbor, MI, USA, 2014.

11. Da Lio, C.; Teatini, P.; Strozzi, T.; Tosi, L. Understanding Land Subsidence in Salt Marshes of the Venice Lagoon from SAR Interferometry and Ground-Based Investigations. Remote Sens. Environ. 2018, 205, 56-70. [CrossRef]

12. Di Paola, G.; Alberico, I.; Aucelli, P.P.C.; Matano, F.; Rizzo, A.; Vilardo, G. Coastal Subsidence Detected by Synthetic Aperture Radar Interferometry and Its Effects Coupled with Future Sea-Level Rise: The Case of the Sele Plain (Southern Italy). J. Flood Risk Manag. 2018, 11, 191-206. [CrossRef]

13. Meire, P.; Ysebaert, T.; Damme, S.V.; den Bergh, E.V.; Maris, T.; Struyf, E. The Scheldt Estuary: A Description of a Changing Ecosystem. Hydrobiologia 2005, 540, 1-11. [CrossRef]

14. Van Damme, S.; Struyf, E.; Maris, T.; Ysebaert, T.; Dehairs, F.; Tackx, M.; Heip, C.; Meire, P. Spatial and Temporal Patterns of Water Quality along the Estuarine Salinity Gradient of the Scheldt Estuary (Belgium and The Netherlands): Results of an Integrated Monitoring Approach. Hydrobiologia 2005, 540, 29-45. [CrossRef]

15. Jongepier, I.; Soens, T.; Thoen, E.; Van Eetvelde, V.; Crombé, P.; Bats, M. The Brown Gold: A Reappraisal of Medieval Peat Marshes in Northern Flanders (Belgium). Water Hist. 2011, 3, 73-93. [CrossRef]

16. Jacobs, P.; Polfliet, P.; De Ceukelaire, M.; Moerkerke, G. Toelichtingen Bij de Tertiairgeologische Kaart van België, Vlaams Gewest, Kaartblad 15 Antwerpen Lier 1/50000; Belgische Geologische Dienst en het Ministerie van de Vlaamse Gemeenschap, Afdeling natuurlijke Rijkdommen en Energie: Brussels, Belgium, 2010.

17. Kiden, P. The Lateglacial and Holocene Evolution of the Middle and Lower River Scheldt, Belgium. Temp. Palaeohydrol. 2001, 283-299.

18. Bogemans, F.; Meylemans, E.; Jacops, J.; Perdaen, Y.; Storme, A.; Verdurmen, I.; Deforce, K. The Evolution of the Sedimentary Environment in the Lower River Scheldt Valley (Belgium) during the Last 13,000 a BP. Geol. Belg. 2012.

19. Meylemans, E.; Bogemans, F.; Storme, A.; Perdaen, Y.; Verdurmen, I.; Deforce, K. Lateglacial and Holocene Fluvial Dynamics in the Lower Scheldt Basin (N-Belgium) and Their Impact on the Presence, Detection and Preservation Potential of the Archaeological Record. Quat. Int. 2013, 308, 148-161. [CrossRef]

20. Kiden, P.; Baeteman, C. Holocene Water Level Movements in the Lower Scheldt Perimarine Area. Prof. Pap. Geol. Dienst Belg. 1989, 241, 1-19.

21. Laga, P.; Louwye, S.; Geets, S. Paleogene and Neogene Lithostratigraphic Units (Belgium). Geol. Belg. 2002, 4, 135-152. [CrossRef]

22. Matthijs, J.; Lanckacker, T.; De Koninck, R.; Deckers, J.; Lagrou, D.; Broothaers, M. Geologisch 3D Lagenmodel van Vlaanderen En Het Brussels Hoofdstedelijk Gewest-Versie 2, G3Dv2; Vlaam. Overheiddepartement Leefmilieunatuur En Energ. Afd. Land En Bodembeschermingondergrondnatuurlijke Rijkdommen: Brussel, Belgium, 2013.

23. Jacobs, P.; De Ceukelaire, M. The New Geological Map of Flanders; AGRIS: Rome, Italy, 2000.

24. Bultynck, P.; Dejonghe, L. Lithostratigraphic Scale of Belgium. Geol. Belg. 2001, 4.

25. Hooper, A. A Multi-Temporal InSAR Method Incorporating Both Persistent Scatterer and Small Baseline Approaches. Geophys. Res. Lett. 2008, 35. [CrossRef]

26. Kampes, B.; Usai, S. Doris: The Delft Object-Oriented Radar Interferometric Software. In Proceedings of the Proc. 2nd Int. Symp. Operationalization of Remote Sensing; Citeseer: Princeton, NJ, USA, 1999; pp. 16-20.

27. Perissin, D.; Wang, Z.; Wang, T. The SARPROZ InSAR Tool for Urban Subsidence/Manmade Structure Stability Monitoring in China. In Proceedings of the 34th International Symposium on Remote Sensing of Environment, Sydney, Australia, 10-15 April 2011.

28. Rosen, P.; Hensley, S.; Peltzer, G.; Rogez, F.; Simons, M.; Crampe, F.; Lohmann, R. A Repeat Orbit Interferometry Package. 2000. Available online: https://trs.jpl.nasa.gov/bitstream/handle/2014/14251/00-0663.pdf? sequence=1 (accessed on 10 February 2021). 
29. Farr, T.G.; Rosen, P.A.; Caro, E.; Crippen, R.; Duren, R.; Hensley, S.; Kobrick, M.; Paller, M.; Rodriguez, E.; Roth, L. The Shuttle Radar Topography Mission. Rev. Geophys. 2007, 45. [CrossRef]

30. Chaussard, E.; Wdowinski, S.; Cabral-Cano, E.; Amelung, F. Land Subsidence in Central Mexico Detected by ALOS InSAR Time-Series. Remote Sens. Environ. 2014, 140, 94-106. [CrossRef]

31. Declercq, P.-Y.; Gerard, P.; Pirard, E.; Perissin, D.; Walstra, J.; Devleeschouwer, X. Subsidence Related to Groundwater Pumping for Breweries in Merchtem Area (Belgium), Highlighted by Persistent Scaterrer Interferometry. Int. J. Appl. Earth Obs. Geoinf. 2017, 63, 178-185. [CrossRef]

32. Smitz, H. De Ontwikkeling van de Haven van Antwerpen de Voorbije 75 Jaar En de Relatie Tot de Scheldepolders: Deel 2. In Waterbouwkundig Laboratorium 1933-2008; JPI Oceans AISBL: Brussels, Belgium, 2011; pp. 1-150.

33. Bogemans, F. Technisch Verslag Bij de Opmaak van de Quartairgeologische Kaart van Vlaanderen; Vlaam. Overheiddienst Nat. Rijkdommen: Brussel, Belgium, 2005.

34. Campeny, L.; Sevrin, L.; Valentim, P. Les Quais d'Anvers Réaménagement Des Berges de l'Escaut; Université de Liège: Liège, Belgium, 2013.

35. Adams, R.; Vermeire, S.; De Moor, G.; Jacobs, P.; Louwye, S.; Polfliet, T. Toelichting Bij de Quartairgeologische Kaart. Kaartblad 15 Antwerp. 2002.

36. Home I National Commission for Stratigraphy Belgium. Available online: https://ncs.naturalsciences.be/home (accessed on 1 June 2020).

37. Van Burm, P.; Maertens, J.; E De Beer, E. Grondmechanische Kaart 15.3.1. Antwerpen Petroleumhaven; Rijksinstituut Voor Grondmechanica: Gent, Belgium, 1982. 